\title{
Cultura afro-brasileira e diversidade
}

\author{
Culture afro-Brazilian and diversity
}

Culture afro-brésilienne et diversité

\author{
Letícia Augusta ARAKAKI
}

\begin{abstract}
RESUMO
Este depoimento se refere à minha experiência como aluna/ professora a partir da participação em "espaço de criação" desenvolvido pela professora Nilce da Silva, cujo tema abordado foi a questão da cultura afrobrasileira e a diversidade. Relato aqui um pouco do trabalho que foi desenvolvido com as crianças relacionando a questão da diversidade étnicoracial, cultural e social, visando a valorização da história, das contribuições africanas para a cultura brasileira eda identidade dôs afrodescendentes.

Palavras-chave: Diversidade, cultura, afro-brasileiros, identidade.

\section{ABSTRACT}

This report mentions my experience as student/teacher through the participation in "space of creation" developed by Nilce da Silva, treating of the question of Afro-Brazilian culture and diversity. Here I expound some of the work that was developed with the children having related the question of the ethnic-racial, cultural and social diversity, aiming at: valuation of history, the African contributions for the Brazilian culture and of the identity of the afro descendents.
\end{abstract}

Index terms: Diversity, culture, Afro-Brazilian, identity.

\section{RESUME}

Ce témoignage se réfère à mon expérience comme élève/ enseignante à partir de la participation du "espace de création" ; développé par le professeur Nilce da Silva, dont le sujet abordé a été la question de la culture afro-brésilienne et la diversité. Je raconte ici, un peu, le travail qui a été développé avec les enfants concernant la question de la diversité ethnoracial, culturel et social, en vue de la valorisation de l'histoire, des contributions africaines pour la culture brésilienne et de l'identité des afrodescendants. 
Mots-clés: Diversité, culture, afro-brésiliens, identité.

\section{Depoimento}

O presente relato refere-se à minha experiência como professora/ estudante em sala de aula a partir da minha participação em "espaço de criação" coordenado pela professora doutora Nilce da Silva, da Faculdade de Educação da Universidade de São Paulo.

O tema por mim proposto foi "Cultura afro-brasileira e diversidade" para a realização deste trabalho com a turma do Mini-Grupo A/B (aproximadamente vinte crianças de três anos de idade), no Centro Educacional Infantil (CEI) Jardim Dionísio, unidade escolar em que também atuo como educadora, atualmente.

O CEI Jardim Dionísio está localizado na região do Jardim Ângela, periferia de São Paulo. O nível sócio-econômico das famílias dos alunos é baixo, com muitos pais desempregados ou com baixa renda e vivendo em condições precárias.

Levando em consideração este contexto e que grande parte dos alunos desta escola é afro-descendente, o trabalho com essa temática pode contribuir para lutar contra discriminações ou combater preconceitos.

Pensar em como trabalhar as questões étnico-raciais e diversidade cultural na Educação Infantil se constituiu, inicialmente, um grande desafio para mim. Conforme refletia sobre o assunto, diversas idéias foram surgindo. Todavia, o fato de a Lei 10.639/03 instituir o estudo da história das culturas africanas e afro-brasileiras somente no Ensino Fundamental e Médio no Brasil, não significa, do nosso ponto de vista, que não precisamos trabalhar essas questões inclusive na Educação Infantil.

Reconhecendo a importância da abordagem dessa temática desde cedo, preocupei-me em trabalhá-la através de uma linguagem, a mais adequada possível, à faixa etária das crianças com o objetivo de oferecer a 
essas crianças, afro-descendentes, referenciais para que se orgulhem de sua origem, fortalecendo a identidade das mesmas enquanto grupo.

Para tanto, propus algumas atividades seqüenciais que tiveram duração de três dias. Não por isso, esse trabalho não se esgotará ao final da nossa proposta, uma vez que atuo como educadora nessa mesma unidade escolar e darei continuidade a ela.

No primeiro dia, fiz uma exposição com cartazes sobre o assunto. Juntamente com as crianças e a professora do Mini-Grupo A, Lúcia, conversamos sobre as contribuições africanas para a cultura brasileira, tais como: feijoada, instrumentos musicais, capoeira etc.

As crianças manusearam alguns instrumentos musicais e ainda ouviram a música de Chico César, Mama África.

Apresentei um pouco da história da chegada dos portugueses e africanos ao território indígena brasileiro, através de fantoches e de outros recursos didáticos.

Procurei explorar os conceitos de multiculturalismo e policulturalismo, ou melhor, o fato de que há múltiplas culturas produzidas pelas sociedades, cada uma com suas peculiaridades e riquezas em elementos simbólicos, em harmonia ou em relação de tensão. E ainda que, na história muitos povos foram dominados por outros, sendo suas culturas praticamente desvalorizadas ou, dependendo do caso, até dizimadas.

As crianças se mostraram interessadas durante a conversa, interagiram bem durante as atividades, demonstraram bastante euforia no manuseio dos instrumentos musicais e ouviram a história com muita atenção. A participação me pareceu satisfatória.

No segundo dia, expus no chão da sala de convivência um cartaz que continha algumas fotografias relacionadas ao legado cultural africano no Brasil. As crianças pareceram bastante instigadas pelo cartaz. Então, fizemos uma roda para conversarmos sobre o assunto. Feito isso, passamos o cartaz para que todos pudessem visualizá-lo de perto. Conforme o 
observavam, as crianças faziam diversos comentários revelando suas hipóteses sobre o assunto. Mostrei-lhes, em seguida, os livros "Bichos da África" 1,2 e 3 e "Jonas e a Sereia", para que pudessem manuseá-los e fizessem a leitura visual. Elas ficaram encantadas com os livros e tudo que lhes chamavam a atenção queriam nos mostrar. Observados os interesses das crianças, mostrei-lhes os livros, evidenciando alguns elementos da cultura africana e outros aspectos, assim como cores, formas, linhas e animais. No final da aula, brincaram com o bumba-meu-boi ao som musical.

No terceiro dia, a turma assistiu ao filme "Kiriku e a feiticeira", com o intuito de oferecer as crianças uma referência de herói negro e discorrer sobre os elementos das culturas africanas apresentados ao longo do filme. Deste modo, enquanto assistiam, evidenciávamos alguns aspectos imateriais ou objetos mostrados para que percebessem elementos diversos da cultura africana, tais como: hábitos, costumes, utensílios, instrumentos musicais, música, dança, gastronomia, vestimenta, artesanato, etc; Mostrei-lhes também o inhame, que foi citado durante o filme como apreciado por uma das personagens (Karabá, a feiticeira) gostava. As crianças ouviram também músicas africanas e observaram diferentes línguas.

Antes de passar o filme para os alunos, fiquei bastante preocupada com o tempo de duração do mesmo, pois, inicialmente, pensei que poderia ser muito "longo" e que as crianças iriam se dispersar. Contudo, ocorreu o contrário. Superou minhas expectativas, uma vez que as crianças prestaram muita atenção e fizeram alguns comentários sobre a cultura e coisas que lhes chamavam a atenção. Enfim, os resultados foram bastante positivos.

Notei que as atividades planejadas e executadas, de modo geral, foram bastante significativas para eles que demonstraram curiosidade e interesse pela temática. Percebi, também, que as crianças estavam comentando os assuntos trabalhados com outras pessoas fora da sala de aula, ou seja, a aprendizagem não se restringiu às atividades realizadas naqueles momentos. 
A curta duração desta proposta não conseguiu dar conta de toda a complexidade e riqueza do assunto, uma vez que é preferível trabalhar poucas coisas, mas bem fixadas, ou muitas coisas em um período maior para se firmar as aprendizagens. Mesmo assim, afirmo que meu trabalho em sala de aula foi muito válido para se começar a pensar nessas questões dentro da própria escola; temática esta que ainda não havia sido mencionada na unidade escolar em questão e que gerou muito interesse por parte de alguns educadores.

Destaco aqui a colaboração da professora e companheira de trabalhoLúcia, e o empenho do coordenador pedagógico- Flávio, que contribuíram significativamente para realização desta minha proposta.

Finalmente, cabem aqui pelo menos dois provérbios que refletem esse estágio:

"Vale mais um passarinho na mão do que dois voando!"

“Uma só andorinha não faz verão!”

\section{Referências bibliográficas:}

ANDRADE, Rogério (1988). Bichos da África: lendas e fábulas. São Paulo: Melhoramentos.

BRASIL. Lei $\mathrm{n}^{\circ}$ 10.639, de 9 de janeiro de 2003. Altera a Lei $\mathbf{n}^{\circ}$ 9.394, de dezembro de 1996, que estabelece as diretrizes e bases da educação nacional, para incluir no currículo oficial da Rede de Ensino a obrigatoriedade da temática "História e Cultura Afro-Brasileira", e dá outras providências. Disponível em: <http://www.planalto.gov.br/ccivil_03/leis/2003/110.639.htm>

GATTAI, Zélia (2001). Jonas e a sereia. S/1: Record.

\section{Filme:}

Kiriku e a feiticeira (Kiriku et la Sorcière), França/Bélgica/Luxemburgo, 1998, 71 min, Direção: Michel Ocelot. 


\section{Autora:}

Letícia Augusta Arakaki

Graduanda em Pedagogia na Faculdade de Educação da Universidade de São Paulo. Professora de Educação Infantil e Ensino Fundamental (Ciclo I) em escolas da rede pública e particular, desde o ano de 2003. Formada no Curso Normal de Nível Médio no C.E.F.A.M. (Centro Específico de Formação e Aperfeiçoamento do Magistério) de Itapecerica da Serra, em 2002.

Contato: leticiaarakaki@yahoo.com.br

\section{Como citar este depoimento:}

ARAKAKI Letícia Augusta. Cultura afro-brasileira e diversidade. Revista ACOALFAplp: Acolhendo a Alfabetização nos Países de Língua portuguesa, São Paulo, ano 4, n. 7, 2009. Disponível em: <http://www.acoalfaplp.net>. Publicado em: setembro 2009.

Recebido em julho de 2008./ Aprovado em setembro de 2008. 